Review

\title{
Review of Potential Energy Storage in Abandoned Mines in Poland
}

\author{
Candra Saigustia *(D) and Sylwester Robak
}

Citation: Saigustia, C.; Robak, S. Review of Potential Energy Storage in Abandoned Mines in Poland. Energies 2021, 14, 6272. https://doi.org/ $10.3390 /$ en14196272

Academic Editors: Antonio Rosato and Victor Becerra

Received: 1 July 2021

Accepted: 27 September 2021

Published: 1 October 2021

Publisher's Note: MDPI stays neutral with regard to jurisdictional claims in published maps and institutional affiliations.

Copyright: (c) 2021 by the authors. Licensee MDPI, Basel, Switzerland. This article is an open access article distributed under the terms and conditions of the Creative Commons Attribution (CC BY) license (https:// creativecommons.org/licenses/by/ $4.0 /)$.
Faculty of Electrical Engineering, Warsaw University of Technology, 00-662 Warsaw, Poland; sylwester.robak@pw.edu.pl

* Correspondence: candra.saigustia.dokt@pw.edu.pl

\begin{abstract}
Poland has had a total of 70 mines, but now more than half of them is out of operation. This mining closure raises with respect to the environment and unemployment. Innovative technology is needed to overcome the problems that arise and could simultaneously make use of abandoned mine infrastructure. The increased electricity generation coming from renewable energy, which produces fluctuating and intermittent energy for the electric power system, causes frequency problems such that energy storage technologies are needed. Abandoned mines can be used for the implementation of energy storage plants. This paper explores the possibility of using abandoned mines in Poland for electrical energy storage. Closed mines can be used to store clean and flexible energy. This idea has the potential to support sustainable economic development within the community following mine closure in Poland.
\end{abstract}

Keywords: electrical energy storage; electrical energy storage in abandoned mines; energy transition of Poland

\section{Introduction}

By 2040, global energy demand will increase significantly, and the demand for energy sourced from renewable sources is also predicted to have increased by $15 \%$ [1]. The European Commission has also targeted $27 \%$ of total energy produced globally by 2030 being renewable energy [2]. The acceleration of infrastructure development for renewable energy sources with low emissions and high efficiency is being carried out intensively in order to achieve this target.

The European Union's climate and energy policies have a significant impact on Poland's national energy strategy, especially with respect to energy transition. The use of renewable energy sources (RES) in Poland is growing fast and continues to increase. Last year, energy production from RES in Poland amounted to nearly $28 \mathrm{TWh}$, and in 2020, PV energy production increased to a level 3.5 times higher than that in the previous year. In addition, onshore wind power plants were also put into operation [3].

The use of electrical energy generated from renewable energy sources such as solar and wind pose a massive problem for the stability of the power grid due to its intermittent nature. To overcome this problem, technology that is able to produce flexible electrical energy, striking a balance between supply and demand, is needed. Energy storage systems (ESS) are emerging as one of the key solutions for effectively integrating high shares of solar and wind renewables into power systems in Poland [3].

Energy storage systems can be very useful in improving the quality, reliability, and performance of electrical power systems. There are a range of energy storage technologies that exist nowadays, and each of these different technologies has specific applications. These technology categories can be distinguished on the basis of their working principles and their typical scale of application. There are five main categories of energy storage system, namely chemical, electrochemical, electrical, mechanical, and thermal. 
Guney and Tepe [4] provide a thorough explanation of the energy storage system, including its characteristics, benefits, environmental effect, and implementation options. Aneke and Wang [5] investigated the ways in which a variety of different energy storage systems were implemented and performed. Luo et al. [6] presented a comparison of the many types of electrical energy storage systems on the basis of economic and technical data. Hall and Bain [7] examined the scientific and engineering requirements of different storage systems, describing the state of the technology and development of superconductors, flywheels, and electrochemical energy storage. Previous studies have frequently been limited in terms of the types of energy storage considered. Some studies, for example, focus solely on the sort of energy storage required for a certain application, such as utility applications.

A broader study of all forms of energy storage should be conducted to gain a better understanding of their characteristics, possible integration opportunities, and policy development requirements. Furthermore, with such a wide energy storage sector and numerous technical and economic papers released each year, the most recent evaluations are critical for publications aiming to provide reviews on a variety of issues.

The mining sector plays a critical role in meeting energy needs and supporting the economic development of the country. The coal and lignite mining sector is also an important part of the Polish economy. Despite the downturn over the past few decades, Poland remains the largest hard coal producer in Europe, and has much larger reserves compared with other EU member states [8]. Hard coal reserves that can be exploited are located in Upper Silesia and in the Lublin basin in eastern Poland [8]. Hard coal and lignite are used to meet Poland's electrical energy needs, accounting for a percentage of 78.3\%, or around 133 TWh, in 2018 [8]. Lignite is mostly extracted from open mines or tunnels, while coal mines operate both on the surface and underground. Figure 1 shows the areas of lignite and hard coal mining in Poland. Total coal production in Poland has decreased by more than $50 \%$, from 150 million tons in 1990 to 70 million tons of coal in 2016 . This is due to the closure of coal mines, with 40 of the 70 total mines in Poland having closed [9].

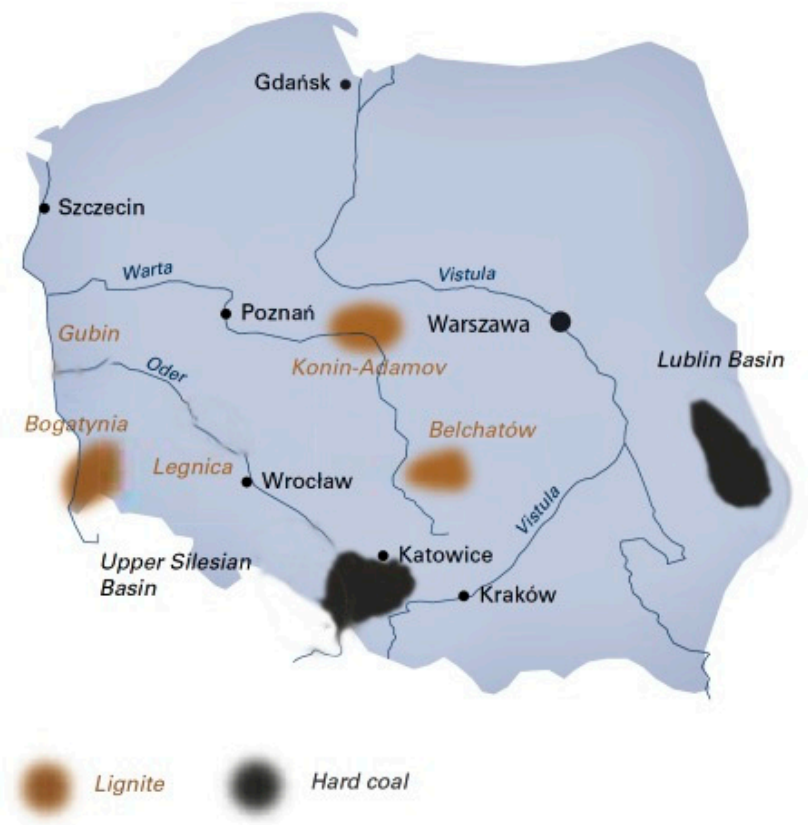

Figure 1. Location of main hard coal and lignite mining areas in Poland.

Poland has four rock salt deposits that are actively managed and utilized, two of them as underground salt mines (Sieroszowice/Kazimierzów and Kłodawa) and the other two as a storage for gas and oil (Góra and Mogilno) [10].

Apart from increasing the unemployment rate and decreasing the amount of coal production, the closure of mine sites has also had an impact on the environment. Technology 
that can reduce these impacts as well as turn the mines into new sources of energy supply is urgently needed. Based on studies [11,12], Poland has 28 active underground mines, with a depth of $300-800 \mathrm{~m}$ and a water outflow of $209 \mathrm{Mm}^{3} /$ year. It is possible that mines that are no longer in operation can in the future be used for underground energy storage.

The infrastructure in abandoned mine areas, such as excavation, space and pumping installations, need to be optimally reused using innovative technology in order to possess greater added value, rather than just being used for waste disposal or being left alone to become an environmental problem. Typically, Underground Hydro Energy Storage (UPHES) and Underground Gas Storage (UGS) are proposed as uses for abandoned coal mines, and Compressed Air Energy Storage (CAES) has been analyzed for its applicability in abandoned salt mines. Moreover, a new concept of gravity energy storage with suspended weight is emerging, which has high potential for use in abandoned mines.

This paper reviews the types of electrical energy storage that can be applied to abandoned mines in Poland by focusing on a comparison of their operating principles, technological factors, advantages, and disadvantages. Several papers on a variety of topics, including the novelty of energy storage, were studied, and are briefly discussed. Some review papers in the literature provide a more detailed review of one energy storage topic, such as a review of hydrogen energy storage, whereas the purpose of this paper is to provide an overview of several electrical energy storage technologies that may be utilized in abandoned mines in Poland, as well as to draw comparisons between these systems. Due to the great amount of information on particular topics, some relevant articles were unable to be included, as they did not fit the aim of this article.

\section{Hydroelectric Energy Storage}

\subsection{Pumped Hydroelectric Energy Storage (PHES)}

PHES is a conventional technology for storing electrical energy. This storage technology dominates the energy storage systems used around the world, with a total capacity of up to $180 \mathrm{GW}$ [13]. The working principle of this system is to utilize the potential energy of water in reservoirs placed at different heights. These reservoirs are connected to the penstock, pump unit and turbine. The process of storing or charging occurs when the load demand on the power grid is not too high, in which case the electrical energy from the grid is used to drive the pump, pumping water from the lower reservoir up, and the process of discharging takes place when electricity demand is high, in which case water from the upper reservoir flows down, driving a turbine and producing electrical energy [14]. Usually, a river is used as the lower reservoir in PHES systems. In Poland, the total capacity of PHES is 1.714 MWe (Table 1).

Table 1. Pumped Hydroelectric Energy Storage power plants in Poland [15].

\begin{tabular}{ccccc}
\hline No. & Name & Location & Head (m) & Capacity (MW) \\
\hline 1 & Dychow & Lubuskie & 30 & 79.5 \\
2 & Solina & Solina & 60 & 200.2 \\
3 & Czorsztyn-Niedzica & Małopolskie & 46.1 & 93 \\
4 & Porabka-Zar & Slaskie & 439 & 500 \\
5 & Żarnowiec & Pomorskie & 119.3 & 680 \\
6 & Żydowo & Wielkopolskie & 81 & 150 \\
\hline Total & & & 1713.7 \\
\hline
\end{tabular}

The PHES system has an efficiency ranging from 70 to $80 \%$ [16-18]. Although the efficiency of the storage system is not too high, other benefits can be obtained as a result of variations in the selling price of electricity.

Using PHES has many advantages. By using PHES systems, the excess energy produced by power plants can be optimized when demand for electricity is low. Moreover, this system is able to balance the frequency stability of the electric power system when the grid is dominated by power generation generated from renewable energy sources such as PV 
and wind [17]. In addition, PHES systems generally have a large capacity, such that this energy storage technology can be used to meet large-scale electrical energy needs [19]. PHES also has the advantage of a shorter response time compared to conventional power plants.

\subsection{Underground Pumped Hydroelectric Energy Storage (UPHES)}

PHES has limitations with respect to expansion and development, because this storage system is highly dependent on topography. PHES has a minimum requirement in height between the two reservoirs, and faces challenges with respect to public acceptance, as well as having a large impact on the environment [20]. To solve these problems, the conventional PHES system can be modified by placing or building a reservoir underground. From an economic point of view, the concept of UPHES systems is more convenient, because the construction of the underground reservoir will not spoil the view in mountainous areas [21]. The lower water reservoir in UPHES is a cavern or underground cavity (Figure 2) [22]. In addition, an underground reservoir can be constructed directly below the upper reservoir, such that the horizontal distance between the two reservoirs is optimal, and the connecting waterways can be minimized [23]. An underground reservoir can be formed by making an excavation, but excavations in abandoned mine areas can also be reused for this purpose [24-26].

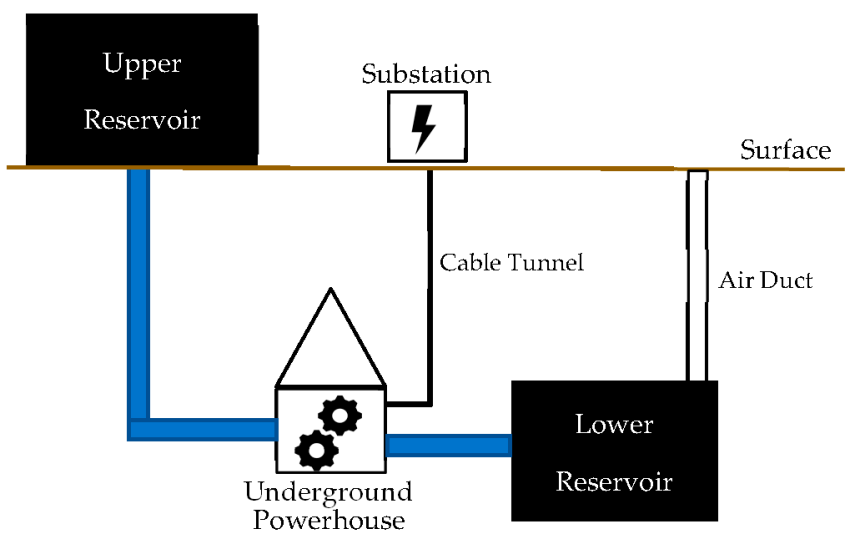

Figure 2. Diagram of UPHS, where the lower water reservoir is an underground cavern or mine. Adapted from [22].

With the UPHES system, a smaller reservoir can produce the same energy output as the PHES system, because the UPHES system has a greater distance between the reservoirs [27]. The energy capacity that can be stored by an energy storage system can be formulated as a function of water potential energy with the following general equation:

$$
P=\rho g Q H \eta
$$

where:

$\rho=$ density of water $\left(1000 \mathrm{~kg} / \mathrm{m}^{3}\right)$

$g=$ acceleration due to gravity $\left(9.81 \mathrm{~m} / \mathrm{s}^{2}\right)$

$Q=$ discharge through the turbine $\left(\mathrm{m}^{3} / \mathrm{s}\right)$

$H=$ hydraulic net head, discounting head loss (m)

$\eta=$ turbine and generator efficiency, which is usually around $90 \%$.

The UPHES system makes it possible to utilize abandoned mining excavation infrastructure. The height difference in the system is obtained by installing a reservoir that is at ground level, while another reservoir is built using a mine excavation or a shaft that is underground. The main components of the UPHES system, including the powerhouse, turbine and generator, can be located underground. Both reservoirs can be underground; however, UPHES systems that place one reservoir above ground are preferred because 
they have lower engineering costs, are more effective, and can also store a larger amount of energy [20].

The implementation of UPHES systems in mining areas that are no longer operational can take advantage of existing mining infrastructure such as pumps, excavations or shafts, pump rooms, and channels that are already connected to the grid. Water entering the mine excavation must be balanced with routine drainage, so that the cavity or space under the ground remains dry and protected from flood water that may have been contaminated and could be dangerous [21,28].

The operation and exploration of hard coal mines in Poland takes place at several different depths, e.g., Budryk (levels: 700 m, 900 m, 1050 m, 1290 m), Ruda Ruch Halemba (levels: 380 m, 525 m, 830 m, 1030 m), Ruch Staszic (levels: 500 m, 720 m, 980 m), and Mysłowice-Wesoła (levels: $465 \mathrm{~m}, 665 \mathrm{~m}, 865 \mathrm{~m}$ ) [29-31]. The above parameters make it possible to consider the use of UPHES technology. However, further research on the impact of this technology on the underground and above-ground environment is be required.

\section{Compressed Air Energy Storage}

Another type of energy storage technology that can take advantage of former mining excavations as storage areas for energy is underground compressed air energy storage (CAES). This system can also store large amounts of energy, but the storage capacity is lower than that for UPHES systems. The CAES system utilizes the potential energy of compressed air stored in the underground reservoir. This air pressure is then enhanced using a compressor driven by electric power [32,33]. In the CAES system (Figure 3), ambient air is compressed and stored in the reservoir, and when a peak load or greater power supply is required, the compressed air in the reservoir is heated and expanded in the turbine to then drive the generator to generate electricity [34]. Research on CAES systems began to be carried out intensively in 1970, and further research is now becoming more serious because of its benefits in providing electricity grid frequency stability due to the high penetration of generators from renewable energy sources that have high intermittency properties [35,36].

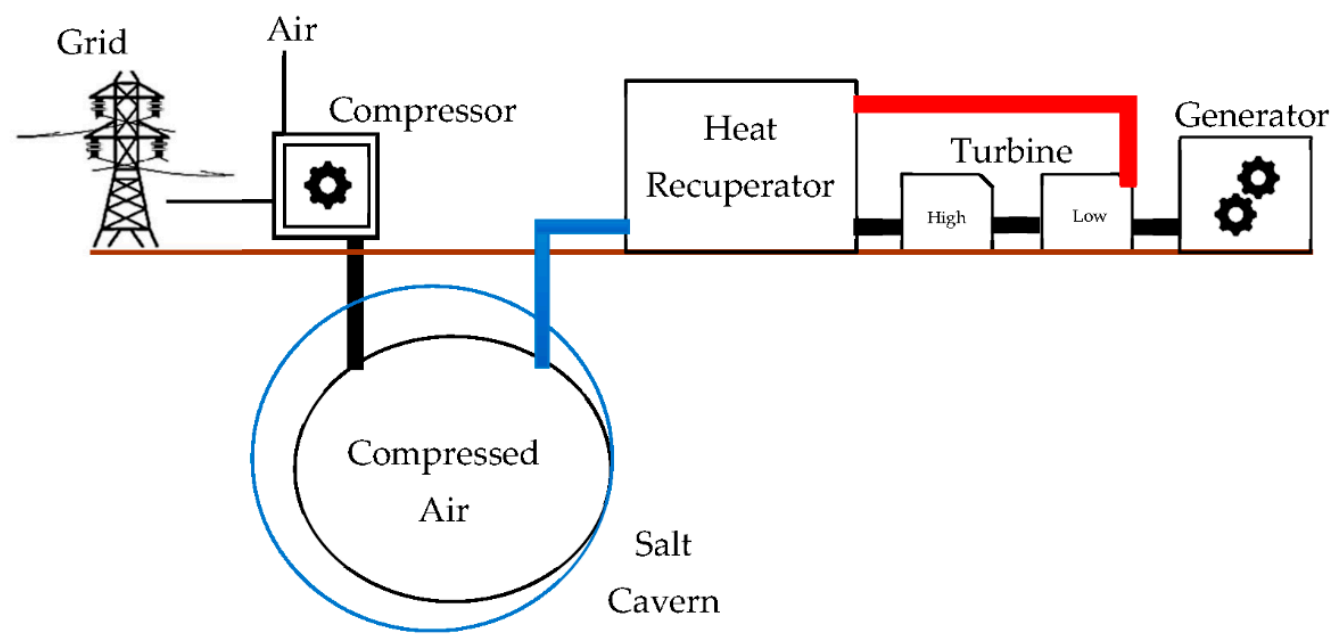

Figure 3. Scheme of Diabatic CAES system. Adapted from [23].

Unlike the PHES system, the CAES system is not limited by topographical conditions, and therefore be implemented in available locations. CAES systems can store large amounts of energy or capacity at relatively low cost [35]. This system additionally profits from variations in the selling price of electricity between off-peak and peak load. This storage system can support electrical load management, restore electrical systems in the event of a blackout, and is able to achieve full load in less than $10 \mathrm{~min}$ after performing system start-up [37]. In addition, CAES plants are also able to provide peak load shaving services, provide compensation for reactive power, and spinning reserve. 
The CAES system stores energy in the form of the potential energy of compressed air, which is stored in a reservoir and then converted into electrical energy when it is needed. In off-peak periods, excess electricity is used to drive the compressor to produce compressed air. Meanwhile, when the electrical system is in the peak load demand period, this pressurized air is released to drive the turbine, which drives the generator to produce electricity for distribution to the grid. The gas or air cools down during the release process, and increases in temperature when compressed. This process can reduce the efficiency of the system, such that the compressor requires cooling fins to reduce the temperature of the air during the compression process, while there is also a combustion chamber to heat the gas during the discharge process before going to the turbine [32,38].

On the basis of the process employed, CAES systems can be divided into three types:

1. Adiabatic or A-CAES: This method processes the heat generated by the compressor to increase the initial temperature of the compressed air, then utilizes cold air during the release of the gas to cool the compressor.

2. Diabatic or D-CAES: In the diabatic process, the heat exchange process does not occur as it does in A-CAES. The heat generated by the compressor is released into the atmosphere temporarily to increase the temperature of the gas during the release or expansion process before going to the turbine, a combustion chamber, which usually uses natural gas combustion, is used.

3. Isothermal: In this system, constant heat exchange is used to maintain a quasiconstant temperature in the environment, so that when the compression process and air expansion take place in the reservoir, the temperature remains at a stable or constant condition. The drawback of this system is that it is only effective in CAES systems with a low power level [38].

Of the three types of CAES system mentioned above, the A-CAES system is preferred because it has the highest efficiency. In addition, adiabatic systems are also less dependent on fossil fuels. When compressing air in the reservoir using an adiabatic process, not much heat is lost, and the temperature changes tend to be stable [35]. However, the ACAES system requires a larger storage area than D-CAES to produce the same amount of energy [38]. To increase the air temperature during expansion, in the D-CAES system, compressed air is mixed with natural gas fuel in the combustion chamber before driving the turbine. The power requirements of the compressor and the power generated by the turbine can be obtained from the following equations:

$$
\begin{gathered}
P_{C}=m_{a}\left(h_{c 2}+h_{c 1}\right), \\
P_{T}=\left(m_{a}+m_{N G}\right)\left(h_{e 2}+h_{e 1}\right),
\end{gathered}
$$

where $P_{C}$ is the power required by the compressor and $P_{T}$ is the power produced by the turbine $(\mathrm{kW}), m_{a}$ is the mass flow of air $(\mathrm{kg} / \mathrm{s})$ and $m_{N G}$ is the natural axis $(\mathrm{kg} / \mathrm{s}) .\left(h_{c 2}+h_{c 1}\right)$ the enthalpy difference in the compressor during the compression process, and $\left(h_{e 2}+h_{e 1}\right)$ the enthalpy difference in the turbine during the process of expansion.

The energy capacity that can be stored in the CAES system is highly dependent on the volume of the reservoir, the turbine temperature, the discharge time of the compressed air stored in the reservoir, and the design of the power plant. In accordance with Equation (3), if the mass flow rate and the power of the gas turbine are increased, the cycle time will decrease. A CAES plant with a capacity of $300 \mathrm{MW}$ can produce electrical energy for up to $8 \mathrm{~h}$, but the systems require a reservoir with a volume of about $620,000 \mathrm{~m}^{3}$ [35].

To build a CAES plant for energy storage using an abandoned mine, there are several important things that must be considered: geological formations need to be in a condition tending towards stability, it needs to be built at a safe enough depth, as the system will operate using air pressure, and it must also be ensured that the storage area is completely airtight, so that no air can come out. In addition, the reservoir location must also be able to withstand repeated pressure cycles during operation. 
Hard coal mines in Poland are very large, making them suitable for CAES technology. However, in order to apply the CAES technology in abandoned coal mines in Poland, further studies on the impact of this technology on the underground and above-ground environment are necessary.

\section{Underground Gas Energy Storage}

Natural gas storage is usually used to reduce fluctuations and daily peak demand. Natural gas storage is a system that has long been used in various countries [39]. This stored natural gas is usually partly used to fuel heating systems in countries that have cold winters [40]. Natural gas storage is a traditional method that is still used in Poland (Table 2). There are seven natural gas storage facilities available that are still actively operating in Poland. Figure 4 depicts the locations of natural gas storage facilities in Poland.

Table 2. Underground gas storage in Poland [41].

\begin{tabular}{|c|c|c|c|}
\hline \multirow{2}{*}{ No. } & \multirow{2}{*}{ Gas Storage } & \multicolumn{2}{|c|}{ Working Capacity } \\
\hline & & Million $\mathrm{m}^{3}$ & GWh $^{1}$ \\
\hline 1 & KPMG Mogilno & 585.4 & 6521.4 \\
\hline 2 & KPMG Kosakowo & 239.4 & 2669.3 \\
\hline 3 & UGS Husów & 500 & 5650 \\
\hline 4 & UGS Strachocina & 360 & 4078.8 \\
\hline 5 & UGS Swarzów & 90 & 1013.4 \\
\hline 6 & UGS Brzeźnica & 100 & 1126 \\
\hline \multirow[t]{2}{*}{7} & UGS Wierzchowice & 1300 & 14,729 \\
\hline & Sum & 3174.8 & $35,787.9$ \\
\hline
\end{tabular}

${ }^{1}$ Estimated value resulting from the value of combustion heat adopted for conversion.

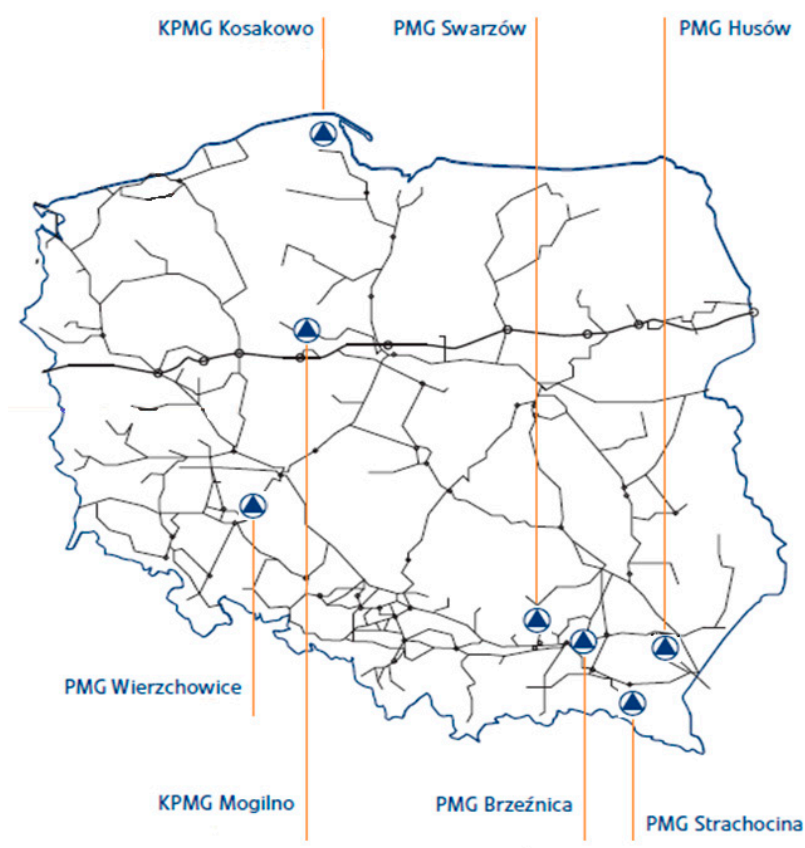

Figure 4. Natural gas storage active in Poland [41].

Natural gas storage or Cavern Underground Gas Stores (KPMG) Mogilno and Kosakowo were built in salt deposits, while other storage facilities have been built in partially depleted natural gas deposits [41].

Excess electricity generated that is not used due to low demand can be converted into gas with the Power to Gas (PtG) system and stored underground. This conversion process can be performed by connecting the UGS with the PtG system. The hydrogen and methane 
gas converted by the PtG system can be stored underground using abandoned mines, salt cavern or gas infrastructure, and then this gas will be converted back into electrical energy to meet peak load demands or when needed. It is also possible to use this gas in other sectors such as for industrial needs or heat supply.

The PtG conversion method (Figure 5) can produce gas through an electrolysis process to separate water into hydrogen and oxygen [42]. So far, there are three methods commonly recognized in the PtG system:

1. The first method is a method that is carried out without additional processing. Hydrogen gas produced from the PtG conversion process is directly injected into the natural gas network, stored in gas storage, or can be used for other purposes that require natural gas [42-45].

2. The second method is a method that is very relevant to the UGS system. In this process, hydrogen $\left(\mathrm{H}_{2}\right)$ and carbon dioxide $\left(\mathrm{CO}_{2}\right)$ are processed by a methanation reaction to produce methane gas $\left(\mathrm{CH}_{4}\right)$ [44]. This methane gas is then injected into the gas distribution network, stored in gas storage, or can be used for all other established natural fuels [44].

3. The third method adds hydrogen to the gas produced by the PtG process to increase the quality of the gas through the electrolysis process. In this method, the gas produces impurities such as carbon dioxide, water, hydrogen sulfide, and particulates. Therefore, this material needs to be removed from the gas, because it can cause damage to the storage pipe installation [42].

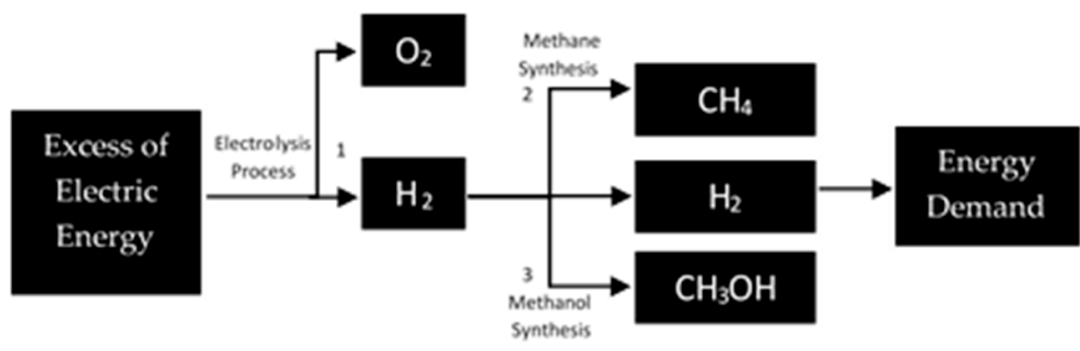

Figure 5. Methods of PtG system: $1 . \mathrm{H}_{2}$ gas is produced from the electrolysis electric energy process; 2. $\mathrm{CH}_{4}$ gas is produced by processing $\mathrm{H}_{2}$ through a methane-synthesis process; $3 . \mathrm{H}_{2}$ treated with a methanol-synthesis process produces methanol $\left(\mathrm{CH}_{3} \mathrm{OH}\right)$; Adapted from [46].

This PtG conversion system has disadvantages in terms of energy efficiency output and high initial investment costs [40]. When using the $\mathrm{H}_{2}$ gas electrolysis process with a pressure of 25 bar, the PtG system can produce an efficiency of around $70 \%$. If the reactor in the methane synthesis process is operated at a pressure of 20 bar, the efficiency will increase by $8 \%$ to $78 \%$, and this is the maximum efficiency level in the chemical electro process [43]. In the subsequent electrolysis process, the efficiency of this system decreases to only about 55\%, and will increase if heat from the reactor is used [44]. The efficiency of the entire process in the PtG system varies widely between 54 and $77 \%$, depending on the process conditions and the technology used; if the gas conversion process is continued to produce methane gas, the efficiency reaches a maximum of about $65 \%$ [47]. Research using reversible solid oxide electrochemical cells and waste heat during the PtG conversion process demonstrated a round-trip efficiency of up to $70 \%$ [48].

It must be ensured that the gas in the UGS system is stored in a very stable, safe, and airtight place. Gas storage rooms or reservoirs commonly used in UGS systems include salt caverns and depleted oil and gas mines [40,49,50]. Gas storage in reservoirs utilizing the excavations in abandoned coal mines and salt mines is also possible [51]. The gas stored with UGS systems in abandoned mining or salt caverns can be used to meet peak energy demands and to balance periods of high demand lasting from several hours to several days [39]. 


\section{Suspended Weight Energy Storage}

The implementation of PHES technology has limitations with respect to the selection of suitable land, because the system requires a sufficient height difference between the two reservoirs [52]. This has encouraged the development of new forms of gravity energy storage utilizing pumped hydropower that is not overly dependent on specific land conditions [53]. A US company called Gravity Power has patented a technology that uses a large suspended underground piston to store energy in the form of energy potential, following which the piston is released to push water through a turbine and drive a generator, generating electrical energy and delivering it to the grid to meet electricity demand at peak loads [54]. The shortcoming of the implementation of this gravity energy storage system is the high capital cost required for excavation and the reinforced concrete containers required, which account for approximately $82 \%$ of the total cost [55].

One way of reducing the cost of the implementation of the gravity energy storage technology is to use existing excavations in abandoned mines. Gravitricity, a UK company, has proposed a new gravity-based energy storage technology concept using suspended weights. Gravity energy storage using suspended weights is a new method for storing energy that could potentially be used in abandoned mines. This system has the advantage of requiring less surface land, and the possibility of being combined with other energy storage systems such as CAES [56]. Although the energy capacity that can be stored using this system is strictly limited to the maximum weight of the piston and the dimensions of the shaft, this type of energy storage technology has high potential for implementation in former mining areas.

The energy storage capacity of the system can be obtained by the following formula:

$$
\mathrm{E}=\eta m g(D-h)
$$

where $\eta$ is the round-trip efficiency, $m$ is the mass of the suspended weight, $g$ is the acceleration due to gravity, $D$ is the depth of the shaft, $h$ is the height of the suspended weight, and $D^{\prime}=D-h$ is the usable depth for energy storage.

Morstyn et al. [57] conducted technical analysis research on the potential use of gravity energy storage using the suspended weight concept in abandoned mine shafts. The results of the research showed that the system could produce a maximum ramp-rate to provide power system services. A report based on the results of a study comparing energy storage technologies suggested that the concept of gravity energy storage could be competitive for grid frequency response in terms of Levelized Cost of Energy Storage (LCOS), and this type of technology has the advantages of high power availability and multiple short cycles, thus making it suitable for rapid frequency response services and the provision of grid balancing.

The design of suspended weight energy storage is similar to the design of a crane with a regenerative braking system [58]. Figure 6 shows a schematic diagram of a gravitybased energy storage system using a suspension weight. Gravity energy storage generally consists of four major components, namely mine shafts, the suspended weight, an induction motor, and an inverter. The motor and inverter can be implemented in parallel to reduce their size. The energy charging and storage process occurs by lifting suspended weights using electrical energy from the grid. Meanwhile, the discharging process takes place by releasing the masses with regenerative braking in order to drive the motor, which converts the potential energy of the suspended weight into electrical energy, and then the electricity generated is connected to the grid or the electrical power system.

Suspended weight energy storage is a very promising technology. The following observation supports this. According to [59], in Poland, the average mine depth (depth of vertical shaft) is over $700 \mathrm{~m}$, and the maximum depth is over $1200 \mathrm{~m}$; meanwhile, in China, the average mine depth is less than $500 \mathrm{~m}$, and in India it is only $150 \mathrm{~m}$. As result, in the future, the following coal mines could initially be considered for suspended weight energy storage: Budryk (shaft depth-1290 m), ROW Ruch Rydułtowy (shaft depth-1150 m), Borynia-Zofiówka-Jastrzębie Ruch Zofiówka (shaft depth—1110 m), Borynia-Zofiówka- 
Jastrzębie Ruch Jastrzębie (shaft depth—1068 m), Knurów-Szczygłowice Ruch Knurów (shaft depth—1050 m), Ruda Ruch Halemba (shaft depth—1030 m), ROW Ruch Marcel and Ruda Ruch Bielszowice and Pniówek (shaft depth-1000 m).

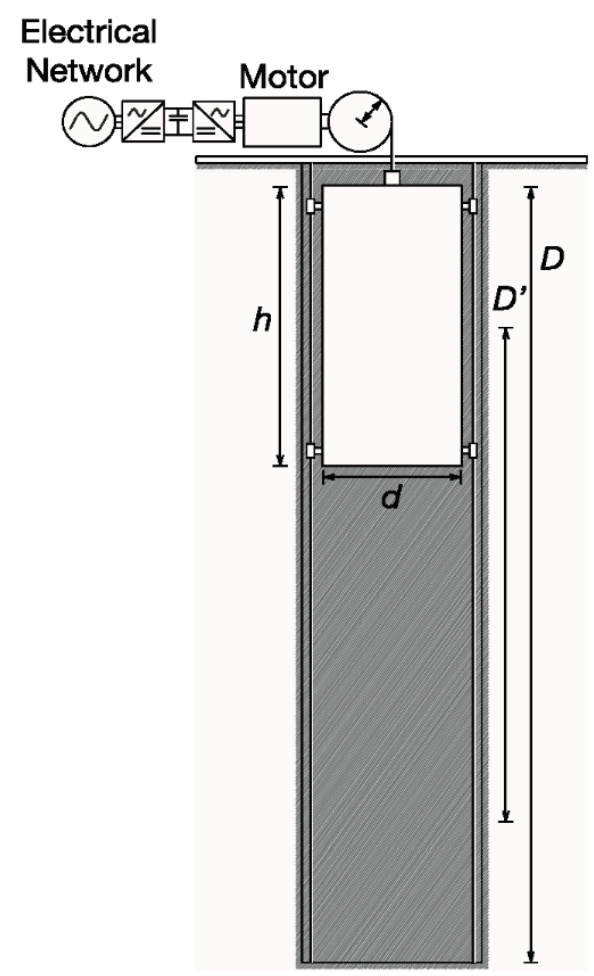

Figure 6. A schematic diagram of a gravity energy storage system using suspended weight [57].

\section{Comparative Analysis of Electrical Energy Storage}

The development of energy storage using abandoned mining infrastructure has several advantages and disadvantages. A comparison of the benefits and drawbacks of electrical energy storage is shown in Table 3. Furthermore, storing energy in an abandoned mine usually has greater operating and maintenance (O\&M) costs than traditional storage systems [22], but using abandoned mine areas for energy storage technology has environmental benefits, and could provide Poland with a flexible energy source.

Table 3. Advantages and disadvantages storage technology [60,61].

\begin{tabular}{|c|c|c|c|}
\hline Name & Advantages & Disadvantages & $\begin{array}{l}\text { Storage } \\
\text { Duration }\end{array}$ \\
\hline PHES & $\begin{array}{c}\text { Technical maturity } \\
\text { High energy storage capacity } \\
\text { Long life cycle } \\
\text { No Location constraints }\end{array}$ & $\begin{array}{l}\text { High cost } \\
\text { Low power and energy density } \\
\text { environmental impacts }\end{array}$ & Hours-months \\
\hline Underground CAES & $\begin{array}{c}\text { Technical maturity } \\
\text { High energy storage capacity }\end{array}$ & $\begin{array}{l}\text { Variable efficiency } \\
\text { Leakage and Safety issues } \\
\text { Location constraints }\end{array}$ & Hours-months \\
\hline UGS, hydrogen & $\begin{array}{c}\text { High Efficiency } \\
\text { Numerous Sources } \\
\text { High energy storage capacity }\end{array}$ & $\begin{array}{c}\text { High cost } \\
\text { Storage Complications } \\
\text { Leakage and Safety issues }\end{array}$ & Hours-months \\
\hline Suspended Weight Energy Storage & $\begin{array}{c}\text { Low Cost } \\
\text { High cyclability } \\
\text { High power availability }\end{array}$ & $\begin{array}{l}\text { Technical immaturity } \\
\text { Low power and energy density }\end{array}$ & - \\
\hline
\end{tabular}


Well-established storage technology systems, such as PHES, face challenges of limited land availability and topographical constraints whereby appropriate height and huge reservoirs are required [62]. In addition, PHES has environmental impacts on the surrounding natural landscapes, as well as facing challenges with respect to community acceptance [63]. Meanwhile, UPHES systems that use abandoned mines have a lower impact. However, UPHES require double the investment cost of PHES, at around 2215 EUR/kW [21]. UPHES plants are becoming more expensive because of the technical costs involved in the construction of underground reservoirs. To build a reservoir for a UPHES system with a capacity of $450,000 \mathrm{~m}^{3}$ costs EUR 127.5 million; this price is much higher than the cost of constructing a reservoir on the surface, which is only EUR 7.4 million [64].

Underground hydroelectric pumped storage (UPHES) has a working principle similar to PHES, but UPHES has a water reservoir that is underground. The use of an underground water reservoir means that the UPHES system does not require a large area on the surface. The potential energy of the water moves vertically in the ground. Menédez et al. [65], Winde et al. [21], and Pujades et al. [27] have conducted case studies on abandoned mines following this working principle. The majority of the costs associated with the use of UPHES technology are spent on the construction of the underground water reservoirs, while the remaining costs are used for engineering work and connection to the grid [22].

In contrast to conventional gas turbines, gas turbines in CAES systems have separate gas expansion and compression processes. CAES systems make available the power supply of the gas turbine during periods of peak load demand. The use of abandoned mine infrastructure for CAES systems can result in reduced environmental impact. In addition, water in the mine area can be used for cooling systems.

The cost of constructing a CAES in a cavern in hard rock increases the initial investment cost by up to $80 \%$ [66]. While the initial investment cost for the CAES technology in a salt cavern is $282 \mathrm{EUR} / \mathrm{kW}$, using an abandoned mine requires an initial cost of 960 EUR/kW [67]. Construction of CAES in coal mines requires a higher initial investment cost than salt caverns, because coal mines require the use of additional materials to ensure that there is no air leakage.

In UGS or PtG technology, there are two types of electrolysis processes for producing hydrogen gas, namely alkaline and polymer electrolyte membrane (PEM). Based on research in [68-71], the total investment cost to be able to produce hydrogen gas through the PEM electrolysis process is twice as high as that for the alkaline process. The UGS system or hydrogen fuel cells require total capital costs of 500-10,000 EUR/kW [72]. The investment price of PtG using an alkaline electrolysis process is around $1000 \mathrm{EUR} / \mathrm{kW}$, which is equivalent to $5060 \mathrm{EUR} / \mathrm{m}^{3} \mathrm{H}^{2}$, and this price is also influenced by the characteristics of the PtG system, such as pressure and size or volume [68,70,73].

In analyzing the use of energy storage systems technology, it is necessary to assess the characteristics of the technology to be used (Table 4). This is because each power plant has its own unique characteristics and requires different integration requirements for connection to the grid system.

There are recent publications and projects in several countries related to energy storage that may be applicable to abandoned mines in Poland. A preliminary investigation into the use of an abandoned mine in Germany for UPHES was conducted [81]. UPHES was mentioned in a recent Dutch study on energy storage, although only conventional PHES was considered in the calculations [82]. Energy Vault, the Swiss company that developed the suspended weight energy storage structure, has already initiated a test program for the first commercial installations that are expected to take place in 2021 [83]. Another project, HyPSTER, is testing large-scale green hydrogen generation and underground storage in French salt caverns [84]. Lutynski [30] focused on the potential benefit of implementing CAES systems in abandoned mines in Poland and compared this to natural gas storage in abandoned coal mines. Another review investigated the technological, geological, and physical difficulties of underground hydrogen storage in the UK, as well as the locations of salt deposits, and legal and economic considerations [85]. The research 
in [86] investigated the potential benefits of UPHES in the Dutch power system, and laid the groundwork for comparing UPHES and battery energy storage (BES) performance in the Dutch power system.

Table 4. Energy storage technology, PHES, CAES, UGS and Suspended Weight.

\begin{tabular}{|c|c|c|c|c|c|}
\hline $\begin{array}{c}\text { Storage } \\
\text { Technology }\end{array}$ & $\begin{array}{c}\text { Energy Density } \\
\text { (Volumetric) } \\
\left(\mathrm{kWh} / \mathrm{m}^{3}\right)\end{array}$ & $\begin{array}{l}\text { Power Density } \\
\left(\mathrm{kW} / \mathrm{m}^{3}\right)\end{array}$ & $\begin{array}{c}\text { Power Capacity/ } \\
\text { Duration }\end{array}$ & $\begin{array}{l}\text { Lifetime } \\
\text { (Cycles) }\end{array}$ & $\begin{array}{c}\text { Cycle Efficiency } \\
(\%)\end{array}$ \\
\hline & $0.2-2[61]$ & $0.1-0.2$ [61] & $\begin{array}{c}3003 \mathrm{MW} / 10 \mathrm{~h} \\
18 \mathrm{~min}[74]\end{array}$ & $>0.5 \times 10^{4}[61]$ & $65-85[61]$ \\
\hline PHES & $\begin{array}{l}0.5-1.5[75] \\
0.5-1.3[76] \\
0.4-1.1[77]\end{array}$ & $\begin{array}{c}0.5-1.5[75] \\
0.01-0.10[76]\end{array}$ & $3003 \mathrm{MW} / 10 \mathrm{~h}$ & $\begin{array}{l}10^{4}-3 \times 10^{4}[62] \\
10^{4}-6 \times 10^{4}[76]\end{array}$ & $\begin{array}{l}70-80[61] \\
70-85[75]\end{array}$ \\
\hline CAES & $\begin{array}{c}2-6[61] \\
3-6[75] \\
0.4-20[76]\end{array}$ & $\begin{array}{c}0.2-0.6[61] \\
0.5-2[75] \\
0.04-10[76]\end{array}$ & $290 \mathrm{MW} / 2 \mathrm{~h} \mathrm{[78]}$ & $\begin{array}{c}>10^{4}[61] \\
10^{4}-3 \times 10^{4}[65,76] \\
>10^{4}[61]\end{array}$ & $\begin{array}{l}41-75[61] \\
60-90[76]\end{array}$ \\
\hline UGS, hydrogen & $500-3000[74]$ & & $1 \mathrm{MW} / 27 \mathrm{~h}$ [79] & $>10^{3}[74]$ & $20-50[74]$ \\
\hline $\begin{array}{l}\text { Suspended Weight } \\
\text { Gravity Storage }\end{array}$ & $1.06-1.6[55,80]$ & $3.13[54]$ & $\begin{array}{c}40 \mathrm{MW} / 15 \mathrm{~min} \\
{[60]}\end{array}$ & 700 [59] & $80-90[54]$ \\
\hline
\end{tabular}

\section{Conclusions}

This paper reviewed and compared the technology available for redeveloping abandoned mine shafts in Poland for the purpose of electrical energy storage. Poland has many abandoned mines, and it is predicted that their number will increase in the future. Using Poland's abandoned mining infrastructure for energy storage plants has numerous advantages. By converting abandoned mines into assets that can generate electricity, offer new power sources, and assist in the transition from high-emission conventional fossil fuel power plants to low-emission renewable energy, the abandoned mines in Poland have the potential to become more profitable. Redeveloping abandoned mines as electrical energy storage systems could be a way of improving congestion in power system distribution and providing a flexible energy supply to counter the intermittency effects resulting from the increasing penetration of renewable energy sources in Poland. Moreover, electrical energy storage systems could support Poland's program of energy transition towards clean energy, open opportunities for new jobs, and save the environment from post-mining challenges.

Comparisons of the implementation of PHES, CAES, UGS and suspended weight energy storage technologies in abandoned mines in Poland were discussed. These energy storage technologies are potentially favorable for further exploration for implementation in abandoned mines in Poland. Different types of energy storage technologies are suitable for specific applications. Among the energy storage types, suspended weight energy storage is likely to be the cheapest energy storage option and requires minimal land-use. PHES and CAES systems seem to be preferable due to their high storage capacity, while UPHES, UGS and suspended weight energy storage are feasible and promising storage technologies, but still require further research and feasibility studies, because they are still immature concepts and have certain problems that need to be overcome before a completely functional technology can be developed. Hydrogen energy storage systems or UGS could result in large changes to the current energy system.

The redevelopment of closed mines as electrical energy storage plants in Poland has significant advantages compared to the use of conventional systems. The conversion of abandoned mines into energy storage would provide assets and new energy resources for Poland, rather than residual or other problems. Nevertheless, surveys and feasibility studies are required to obtain a more detailed understanding of the challenges involved in redeveloping abandoned mines, and to choose the most appropriate electrical energy storage technology in accordance with the conditions of the mines in Poland. The application of 
energy storage systems in abandoned mine projects is interesting-particularly in Poland, which is predicted to have many closed mines in the future-with the aim of switching them from high-emission conventional fossil fuels to low-emission energy sources.

Author Contributions: Conceptualization, C.S. and S.R.; methodology, C.S and S.R.; validation, C.S.; investigation, C.S. and S.R.; resources, C.S.; writing—original draft preparation, C.S.; writing—review and editing, S.R.; visualization, C.S.; supervision, S.R.; project administration, C.S. All authors have read and agreed to the published version of the manuscript.

Funding: This research received no external funding, and The APC was funded by IUDB PW.

Institutional Review Board Statement: Not applicable.

Informed Consent Statement: Not applicable.

Data Availability Statement: Not applicable.

Conflicts of Interest: The authors declare no conflict of interest.

\section{References}

1. World Energy Outlook 2020-Analysis. 2020. Available online: https://www.iea.org/reports/world-energy-outlook-2020 (accessed on 26 April 2021).

2. Renewables: Europe on Track to Reach Its 20\% Target by 2020. 2020. Available online: https://ec.europa.eu/commission/ presscorner/detail/sl/MEMO_17_163 (accessed on 26 April 2021).

3. Energy Policy of Poland until 2040. Available online: https://www.gov.pl/attachment/376a6254-2b6d-4406-a3a5-a0435d18be0f (accessed on 2 April 2021).

4. Guney, M.S.; Tepe, Y. Classification and Assessment of Energy Storage Systems. Renew. Sustain. Energy Rev. 2017, 75, 1187-1197. [CrossRef]

5. Aneke, M.; Wang, M. Energy Storage Technologies and Real-Life Applications-A State of the Art Review. Appl. Energy 2016, 179, 350-377. [CrossRef]

6. Luo, X.; Wang, J.; Dooner, M.; Clarke, J. Overview of Current Development in Electrical Energy Storage Technologies and the Application Potential in Power System Operation. Appl. Energy 2015, 137, 511-536. [CrossRef]

7. Hall, P.J.; Bain, E.J. Energy-Storage Technologies and Electricity Generation. Energy Policy 2008, 36, 4352-4355. [CrossRef]

8. The Voice of Coal in Europe: Poland. Available online: https://euracoal.eu/info/country-profiles/poland/ (accessed on 26 April 2021).

9. Szpor, A.; Ziółkowska, K. The Transformation of the Polish Coal Sector. 2014. Available online: https://www.iisd.org/system/ files/publications/transformation-polish-coal-sector.pdf (accessed on 26 April 2021).

10. Czapowski, G.; Bukowski, K. Salt Resources in Poland at the Beginning of the 21st Century: Stan Zasobów Soli w Polsce Na Poczatku XXI Wieku. Geol. Geophys. Environ. 2012, 38, 189. [CrossRef]

11. Janusz, K.; Ewa, J.; Antoni, C. Changes of Hydrogeological Conditions in the Area of Liquidated Hard Coal Mines in the North-Eastern Part of Upper Silesia Coal Basin (Southern Poland). In Proceedings of the 9th IMWA International Congress, Oviedo, Spain, 20-26 May 2012.

12. Bukowski, P.; Wagner, J.; Witkowski, A. Use of void space in abandoned mines in the upper silesia Coal Basin (Poland). In Proceedings of the IMWA Symposium 2007, Cagliari, Italy, 27-31 May 2007.

13. Global Energy Storage Database I Energy Storage Systems. Available online: https://www.sandia.gov/ess-ssl/global-energystorage-database-home/ (accessed on 26 April 2021).

14. Barbour, E.; Wilson, I.A.G.; Radcliffe, J.; Ding, Y.; Li, Y. A Review of Pumped Hydro Energy Storage Development in Significant International Electricity Markets. Renew. Sustain. Energy Rev. 2016, 61, 421-432. [CrossRef]

15. Hydropower Plants. Available online: https://www.energoprojekt.pl/en/completed-projects/hydro-power-plants (accessed on 26 April 2021).

16. Guittet, M.; Capezzali, M.; Gaudard, L.; Romerio, F.; Vuille, F.; Avellan, F. Study of the Drivers and Asset Management of Pumped-Storage Power Plants Historical and Geographical Perspective. Energy 2016, 111, 560-579. [CrossRef]

17. Rehman, S.; Al-Hadhrami, L.M.; Alam, M. Pumped Hydro Energy Storage System: A Technological Review. Renew. Sustain. Energy Rev. 2015, 44, 586-598. [CrossRef]

18. Yang, C.-J.; Jackson, R.B. Opportunities and Barriers to Pumped-Hydro Energy Storage in the United States. Renew. Sustain. Energy Rev. 2011, 15, 839-844. [CrossRef]

19. Berrada, A.; Loudiyi, K. Operation, Sizing, and Economic Evaluation of Storage for Solar and Wind Power Plants. Renew. Sustain. Energy Rev. 2016, 59, 1117-1129. [CrossRef]

20. Meyer, F. Storing Wind Energy Underground; FIZ Karlsruhe-Leibnz Institute for Information Infrastructure: Eggenstein Leopoldshafen, Germany, 2013. 
21. Winde, F.; Kaiser, F.; Erasmus, E. Exploring the Use of Deep Level Gold Mines in South Africa for Underground Pumped Hydroelectric Energy Storage Schemes. Renew. Sustain. Energy Rev. 2017, 78, 668-682. [CrossRef]

22. Madlener, R.; Specht, J.M. An Exploratory Economic Analysis of Underground Pumped-Storage Hydro Power Plants in Abandoned Deep Coal Mines. Energies 2020, 13, 5634. [CrossRef]

23. Matos, C.R.; Carneiro, J.F.; Silva, P.P. Overview of Large-Scale Underground Energy Storage Technologies for Integration of Renewable Energies and Criteria for Reservoir Identification. J. Energy Storage 2019, 21, 241-258. [CrossRef]

24. San Martín, J.I.; Zamora, I.; San Martín, J.J.; Aperribay, V.; Eguía, P. Energy Storage Technologies for Electric Applications. Renew. Energy Power Qual. J. 2011, 593-598. [CrossRef]

25. Bodeux, S.; Pujades, E.; Orban, P.; Brouyère, S.; Dassargues, A. Interactions between Groundwater and the Cavity of an Old Slate Mine Used as Lower Reservoir of an UPSH (Underground Pumped Storage Hydroelectricity): A Modelling Approach. Eng. Geol. 2017, 217, 71-80. [CrossRef]

26. Pujades, E.; Orban, P.; Bodeux, S.; Archambeau, P.; Erpicum, S.; Dassargues, A. Underground Pumped Storage Hydropower Plants Using Open Pit Mines: How Do Groundwater Exchanges Influence the Efficiency? Appl. Energy 2017, 190, 135-146. [CrossRef]

27. Pujades, E.; Willems, T.; Bodeux, S.; Orban, P.; Dassargues, A. Underground Pumped Storage Hydroelectricity Using Abandoned Works (Deep Mines or Open Pits) and the Impact on Groundwater Flow. Hydrogeol. J. 2016, 24, 1531-1546. [CrossRef]

28. Menéndez, J.; Loredo, J.; Fernandez, J.M.; Galdo, M. Underground Pumped-Storage Hydro Power Plants with Mine Water in Abandoned Coal Mines. In Proceedings of the 13th IMWA International Congress, Rahua, Finland, 29 July 2017.

29. Jastrzębska Spółka Węglowa SA-O nas-Zakłady JSW-Budryk-O Zakładzie. Available online: https://www.jsw.pl/o-nas/zaklady/ budryk/o-zakladzie (accessed on 24 September 2021).

30. Kopalnia Węgla Kamiennego Halemba. Wikipedia, Wolna Encyklopedia. 2021. Available online: https://pl.wikipedia.org/wiki/ Kopalnia_W\%C4\%99gla_Kamiennego_Halemba (accessed on 24 September 2021).

31. Ruch Pokój-O firmie-Polska Grupa Górnicza, S.A. Available online: https://korporacja.pgg.pl/o-firmie/oddzialy/2po (accessed on 24 September 2021).

32. Wang, J.; Lu, K.; Ma, L.; Wang, J.; Dooner, M.; Miao, S.; Li, J.; Wang, D. Overview of Compressed Air Energy Storage and Technology Development. Energies 2017, 10, 991. [CrossRef]

33. Lutyński, M. An Overview of Potential Benefits and Limitations of Compressed Air Energy Storage in Abandoned Coal Mines. IOP Conf. Ser. Mater. Sci. Eng. 2017, 268, 012006. [CrossRef]

34. Energy Storage Association. Compressed Air Energy Storage (CAES). Available online: https:/ / energystorage.org/why-energystorage/technologies/mechanical-energy-storage/ (accessed on 26 April 2021).

35. Layton, L. Compressed Air Energy Storage. Available online: https://pdhonline.com/courses/e365/e365content.pdf (accessed on 26 April 2021).

36. He, W.; Luo, X.; Evans, D.; Busby, J.; Garvey, S.; Parkes, D.; Wang, J. Exergy Storage of Compressed Air in Cavern and Cavern Volume Estimation of the Large-Scale Compressed Air Energy Storage System. Appl. Energy 2017, 208, 745-757. [CrossRef]

37. Succar, S.; Williams, R.H.; Cavallo, A.J.; Christopher, C.K.; Denholm, P.; Dekenberger, D.; Kalinowski, A.; McGill, M.; Socolow, R.; Vann, I. Compressed Air Energy Storage: Theory, Resources, and Applications for Wind Power. Princeton: Princeton Environmental Institute: Princeton, NJ, USA, 2008. Available online: https://acee.princeton.edu/wp-content/uploads/2016/10/ SuccarWilliams_PEI_CAES_2008April8.pdf (accessed on 27 April 2021).

38. Wang, J.; Ma, L.; Lu, K.; Miao, S.; Wang, D.; Wang, J. Current Research and Development Trend of Compressed Air Energy Storage. Syst. Sci. Control Eng. 2017, 5, 434-448. [CrossRef]

39. Bader, A.-G.; Beccaletto, L.; Bialkowski, A.; Jaudin, F.; Hladík, V.; Holecek, J.; Van Gessel, S.; Meinke-Hubeny, F.; Wiersma, F. The ESTMAP Project (Energy Storage Mapping and Planning): Focus on the Subsurface Data Collection. 2016. p EGU2016. Available online: https: / / hal-brgm.archives-ouvertes.fr/hal-01281949 (accessed on 26 August 2021).

40. British Geological Survey. An Appraisal of Underground Gas Storage Technologies and Incidents, for the Development of Risk Assessment Methodology. Research Report; 2008. Available online: https:/ /www.hse.gov.uk/research/rrpdf/rr605.pdf (accessed on 2 March 2021).

41. Ghaib, K.; Ben-Fares, F.-Z. Power-to-Methane: A State-of-the-Art Review. Renew. Sustain. Energy Rev. 2018, 81, 433-446. [CrossRef]

42. Power-to-Gas Energy Storage Is Booming. Available online: https://www.betterworldsolutions.eu/power-to-gas-energystorage-is-booming/ (accessed on 4 April 2021).

43. Eberle, U.; Müller, B.; von Helmolt, R. Fuel Cell Electric Vehicles and Hydrogen Infrastructure: Status 2012. Energy Environ. Sci. 2012, 5, 8780. [CrossRef]

44. Götz, M.; Lefebvre, J.; Mörs, F.; McDaniel Koch, A.; Graf, F.; Bajohr, S.; Reimert, R.; Kolb, T. Renewable Power-to-Gas: A Technological and Economic Review. Renew. Energy 2016, 85, 1371-1390. [CrossRef]

45. Sarić, M.; Dijkstra, J.W.; Haije, W.G. Economic Perspectives of Power-to-Gas Technologies in Bio-Methane Production. J. CO2 Util. 2017, 20, 81-90. [CrossRef]

46. Power-to-Gas-Chemical Storage of Excess Power. Available online: https://www.ens.ei.tum.de/en/research/projects/finishedprojects/p2g/ (accessed on 26 April 2021).

47. Lepszy, S.; Chmielniak, T. Storage System for Electricity Obtained from Wind Power Plants Using Underground Hydrogen Reservoir. J. Power Technol. 2017, 97, 61-68. 
48. Jensen, S.H.; Graves, C.; Mogensen, M.; Wendel, C.; Braun, R.; Hughes, G.; Gao, Z.; Barnett, S.A. Large-Scale Electricity Storage Utilizing Reversible Solid Oxide Cells Combined with Underground Storage of $\mathrm{CO}_{2}$ and $\mathrm{CH}_{4}$. Energy Environ. Sci. 2015, 8, 2471-2479. [CrossRef]

49. Nunes, P. Potencial de Armazenamento Subterrâneo Em Cavidades Salinas de Gás Natural Em Portugal. Master's Thesis, IST-Instituto Superior Técnico, Lisboa, Portugal.

50. Amid, A.; Mignard, D.; Wilkinson, M. Seasonal Storage of Hydrogen in a Depleted Natural Gas Reservoir. Int. J. Hydrog. Energy 2016, 41, 5549-5558. [CrossRef]

51. Current State of and Issues Concerning Underground Natural Gas Storage. Available online: https://www.ferc.gov/sites/ default/files/2020-05/UndergroundNaturalGasStorageReport.pdf (accessed on 2 April 2021).

52. Gimeno-Gutiérrez, M.; Lacal-Arántegui, R. Assessment of the European Potential for Pumped Hydropower Energy Storage Based on Two Existing Reservoirs. Renew. Energy 2015, 75, 856-868. [CrossRef]

53. Botha, C.D.; Kamper, M.J. Capability Study of Dry Gravity Energy Storage. J. Energy Storage 2019, 23, 159-174. [CrossRef]

54. Berrada, A.; Loudiyi, K.; Zorkani, I. Dynamic Modeling and Design Considerations for Gravity Energy Storage. J. Clean. Prod. 2017, 159, 336-345. [CrossRef]

55. Berrada, A.; Loudiyi, K.; Zorkani, I. Sizing and economic analysis of gravity storage. J. Renew. Sustain. Energy. 2017, 8, 1-15. [CrossRef]

56. Fraenkel, P.; Wright, M. Apparatus and Method for Electrical Energy Storage. 2013. Available online: https:/ / patents.google. $\mathrm{com} /$ patent/GB2518125A/en (accessed on 2 June 2021).

57. Morstyn, T.; Chilcott, M.; McCulloch, M.D. Gravity Energy Storage with Suspended Weights for Abandoned Mine Shafts. Appl. Energy 2019, 239, 201-206. [CrossRef]

58. Gravitricity System Offers Lower Cost of Energy Storage. Available online: https://gravitricity.com/gravitricity-offers-lowercost-of-energy-storage/ (accessed on 2 June 2021).

59. Kabiesza, J. Annual Report on the State of Basic Natural and Technical Hazards in Hard Coal Mining. 2018. Available online: https:/ / gig.eu/sites / default/ files / raport_roczny_za_\%202018_rok.pdf (accessed on 22 September 2021).

60. Carnegie, R.; Gotham, D.; Nderitu, D.; Preckel, P.V. Utility Scale Energy Storage Systems. Internal Report of the State Utility Forecasting Group. 2013. Available online: https://www.purdue.edu/discoverypark/energy/assets/pdfs/SUFG/publications/ SUFG\%20Energy\%20Storage\%20Report.pdf (accessed on 16 July 2021).

61. Mueller, S.C.; Sandner, P.G.; Welpe, I.M. Monitoring Innovation in Electrochemical Energy Storage Technologies: A Patent-Based Approach. Appl. Energy 2015, 137, 537-544. [CrossRef]

62. IEC White Paper: Electrical Energy Storage. Available online: https://basecamp.iec.ch/download/iec-white-paper-electricalenergy-storage/ (accessed on 26 April 2021).

63. Kucukali, S. Finding the Most Suitable Existing Hydropower Reservoirs for the Development of Pumped-Storage Schemes: An Integrated Approach. Renew. Sustain. Energy Rev. 2014, 37, 502-508. [CrossRef]

64. Menéndez, J.; Loredo, J.; Galdo, M.; Fernández-Oro, J.M. Energy Storage in Underground Coal Mines in NW Spain: Assessment of an Underground Lower Water Reservoir and Preliminary Energy Balance. Renew. Energy 2019, 134, 1381-1391. [CrossRef]

65. Menéndez, J.; Ordóñez, A.; Álvarez, R.; Loredo, J. Energy from Closed Mines: Underground Energy Storage and Geothermal Applications. Renew. Sustain. Energy Rev. 2019, 108, 498-512. [CrossRef]

66. Electricity Storage and Renewables:Cost and Markets to 2030. 2017. Available online: https://www.irena.org/-/ media/Files/ IRENA/Agency/Publication/2017/Oct/IRENA_Electricity_Storage_Costs_2017.pdf (accessed on 2 May 2021).

67. Schainker, R. Compressed Air Energy Storage (CAES): Scoping Study for California; Electric Power Research Institute: Palo Alto, CA, USA, 2008.

68. Müller-Syring, G.; Henel, M.; Koppel, W.; Mlaker, H.; Sterner, M.; Hocher, T. Entwicklung von Modularen Konzepten zur Erzeugung, Speicherung und Einspeisung von Wasserstoff und Methan ins Erdgasnetz. Abschlussbericht DVGW-Projekt G1-0710: Bonn, Germny, 2013. Available online: https://www.dvgw.de/medien/dvgw/forschung/berichte/g1_07_10.pdf (accessed on 2 June 2021).

69. Sterner, M.; Stadler, I. Energiespeicher_Bedarf, Technologien, Integration, 1st ed.; Springer: Berlin, Germany, 2017.

70. Reytier, M.; Di Iorio, S.; Chatroux, A.; Petitjean, M.; Cren, J.; De Saint Jean, M.; Aicart, J.; Mougin, J. Stack Performances in High Temperature Steam Electrolysis and Co-Electrolysis. Int. J. Hydrog. Energy 2015, 40, 11370-11377. [CrossRef]

71. Etude Portant sur L'hydrogene et la Methanation Comme Procede de Valorisation de L'electricite exc Edentaire. Available online: https: / / www.actu-environnement.com/media/pdf/news-25572-power-to-gas-ademe-grtgaz.pdf (accessed on 26 April 2021).

72. Beaudin, M.; Zareipour, H.; Schellenberglabe, A.; Rosehart, W. Energy Storage for Mitigating the Variability of Renewable Electricity Sources: An Updated Review. Energy Sustain. Dev. 2010, 14, 302-314. [CrossRef]

73. Graf, F.; Gotz, M.; Henel, M.; Schaaf, T.; Tichler, R. Techno-Okonomische Studie von Power-to-Gas-Konzepten. Bonn, Germany, 2014. Available online: https://www.dvgw.de/medien/dvgw/forschung/berichte/g3_01_12_tp_b_d.pdf (accessed on 25 June 2021).

74. Bath County Pumped Storage Station. Available online: https://www.dominionenergy.com/projects-and-facilities/hydroelectricpower-facilities-and-projects/bath-county-pumped-storage-station (accessed on 2 May 2021).

75. Chen, H.; Cong, T.N.; Yang, W.; Tan, C.; Li, Y.; Ding, Y. Progress in Electrical Energy Storage System: A Critical Review. Prog. Nat. Sci. 2009, 19, 291-312. [CrossRef] 
76. Sabihuddin, S.; Kiprakis, A.; Mueller, M. A Numerical and Graphical Review of Energy Storage Technologies. Energies 2014, 8, 172-216. [CrossRef]

77. Nordling, A.; Englund, R.; Hembjer, A.; Mannberg, A. Energy Storage_Electricity Storage Technologies—IVA's Electricity Crossroads Project; Royal Swedish Academy of Engineering Sciences: Stockholm, Sweden, 2016.

78. RWE Power. ADELE-Adiabatic Compressed-Air Energy Storage for Electricity Supply. Available online: https: / / wecanfigurethisout.org/ENERGY/Web_notes/Round_Pegs/Power_Cycles_and_Energy_Storage_Supporting_Files / ADELE\%20\%E2\%80\%93\%20Adiabatic\%20Compressed-Air\%20Energy\%20Storage\%20for\%20Electricity\%20Supply.pdf (accessed on 20 May 2021).

79. Hydrogenics. Available online: http://www.renewableenergyfocus.com/view/35124/german-wind-park-with-1-mwhydrogenics-electrolyser-for-power-to-gas-energy-storage/ (accessed on 20 May 2021).

80. Ruoso, A.C.; Caetano, N.R.; Rocha, L.A.O. Storage Gravitational Energy for Small Scale Industrial and Residential Applications. Inventions 2019, 4, 64. [CrossRef]

81. Alvarado Montero, R.; Wortberg, T.; Binias, J.; Niemann, A. Integrated assessment of underground pumped-storage facilities using existing coal mine infrastructure. Sustainable hydraulics in the era of global change. In Proceedings of the 4th IAHR Europe Congress, Liege, Belgium, 27-29 July 2016.

82. Verzijlbergh, R.; de Vries, L.; Herder, P. Routekaart Energieopslag 2030: Systeemintegratie en Derol van Energieopslag; Report; DNV GL-Energy: Arnhem, The Netherlands, 2015.

83. Gravity Energy Storage Will Show Its Potential in 2021-IEEE Spectrum. Available online: https://spectrum.iee.org/energy/ batteries-storage/gravity-energy-storage-will-show-its-potential-in-2021 (accessed on 18 July 2021).

84. "HyPSTER": Realising the First EU-Supported Large Scale Green Hydrogen Underground Storage Demonstrator. Available online: http:/ / www.element-energy.co.uk/2021/01/hypster-realising-the-first-eu-supported-large-scale-green-hydrogenunderground-storage-demonstrator/ (accessed on 18 July 2021).

85. Scafidi, J.; Wilkinson, M.; Gilfillan, S.M.V.; Heinemann, N.; Haszeldine, R.S. A Quantitative Assessment of the Hydrogen Storage Capacity of the UK Continental Shelf. Int. J. Hydrog. Energy 2021, 46, 8629-8639. [CrossRef]

86. Corbijn, L.J. Benefits of Underground Pumped Hydro Storage (UPHS) in the Dutch Power System. Master's Thesis, Utrecht University, Utrecht, The Netherlands. 